\title{
Evaluations of Insecticides against Cashew Stem and Root Borer, Neoplocaederus ferrugineus (L.)
}

\author{
Lakshmana*, Mahesh Math and T. R. Ranganath \\ Agricultural and Horticultural Research Station, Kapikad, Ullal, Mangaluru-575020 \\ University of Agricultural and Horticultural Sciences, Shivamogga, India \\ *Corresponding author
}

\section{A B S T R A C T}

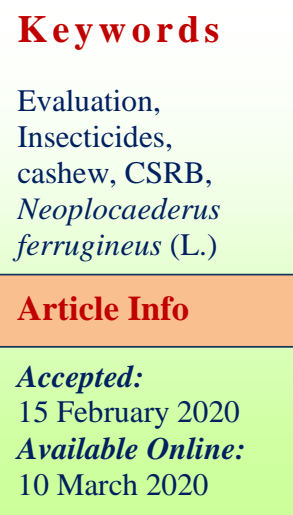

\section{Keywords}

Evaluation,

insecticides,

Neoplocaederus

10 March 2020
Field studies were carried out during 2019-20 at Agricultural and Horticultural Research Station, Ullal, Karnataka, India to evaluate the different insecticides against Cashew Stem and Root Borer (CSRB), Neoplocaederus ferrugineus (L.). Among the different insecticides evaluated, significantly the highest number of Cashew Stem and Root Borer (CSRB) dead grubs was recorded in T5-Aluminium Phosphide @ 10 gm/tree (18.66 dead grubs /tree) followed by T2-Dichlorvos @ $20 \mathrm{ml} /$ tree and T1- Dichlorvos @ $10 \mathrm{ml} /$ tree / litre of water (5.66 and 4.33 dead grubs/tree, respectively). With respect to live grubs of CSRB, significantly the highest number of CSRB live grubs was recorded in T12- Untreated control (20.00 live grub/tree).

\section{Introduction}

Cashew (Anacardium occidentale L.) is a an important foreign exchange earning crop of India. It was originally introduced into India from Brazil by Portuguese travellers during sixteenth century mainly for checking soil erosion on the coast. Initially, it was considered as a suitable crop for soil conservation, afforestation and also wasteland development but gradually gained commercial importance.
Cashew is now widely grown in tropical climates and it has very well adapted to the Indian conditions. In India, it is mainly cultivated in Maharashtra, Goa, Karnataka and Kerala along the West coast and Tamil Nadu, Pondicherry, Andhra Pradesh, Orissa and West Bengal along the East coast. It is also grown to a limited extent in non traditional areas such as Bidar, Kolar, Chitradurga, Bagalkot, Gadag region of Karnataka. 
The production and productivity of cashew is influenced by many factors; among them insect pests is one of the major constraints. As area and productivity of cashew increased, the problem of pests is also increased. In spite of adoption of package of practices, decline in production is mainly due to pest. Cashew is attacked by a number of insect pests during different stages of its growth and development. Around 180 species of insect and non-insect pests were reported to cause substantial yield losses in India (Sundararaju, 1993). Out of these, cashew stem and root borer, is the major pest causing detrimental effect for cashew cultivation.

\section{Materials and Methods}

Field studies were carried out during 2019-20 at Agricultural and Horticultural Research Station, Ullal, Karnataka, India. The different treatments evaluated were listed in (Table 1). The cashew crop spacing was $8 \mathrm{~m} \mathrm{x} 8 \mathrm{~m}$. There were total 12 treatments and three replications. Treatments were imposed to the CSRB infested cashew trees and the damaged trunks were wrapped with transparent polythene sheet after applying the treatments on the trunk up to 1 to 1.5 metres height based on symptom of damage by CSRB. Observations were made every day to check the oozing of frass from the trunk. The dead and live grubs were recorded after ten days of treatment application by removing the bark of the trunk.

\section{Results and Discussion}

The data obtained on efficacy of treatments against cashew stem borer during 2019-20 given in Table 1 . On the $10^{\text {th }}$ day after treatment, significantly highest number of CSRB dead grubs were recorded in $\mathrm{T}_{5^{-}}$ Aluminium Phosphide @ 10 gm/tree (18.66 dead grubs /tree). The next best treatments in recorded highest dead grubs were in $\mathrm{T}_{2}$ -
Dichlorvos@20 ml/tree (5.66) which was on par withT $1_{1}$ - Dichlorvos@ $10 \mathrm{ml} /$ tree / lit of water (4.33). The other treatments viz., $\mathrm{T}_{9^{-}}$ Nepthalene Balls@4/tree, $\mathrm{T}_{10^{-}}$camphor@5 pieces/tree, $\mathrm{T}_{11}$-Only polythene sheet wrapping and $\mathrm{T}_{12^{-}}$Untreated control were recorded with no dead grubs (0.00).

With respect to live grubs after ten days of treatments, significantly the highest number of CSRB live grubs was recorded in $\mathrm{T}_{12^{-}}$ Untreated control (20.00 live grub/tree). The other treatments viz., $\mathrm{T}_{11}$-Only polythene sheet wrapping, $\mathrm{T}_{10}$-Camphour 5 pieces / tree, T9-Nepthalene Balls 4 /tree, $\mathrm{T}_{1}$ - Dichlorvos @ $10 \mathrm{ml} /$ tree / litre of water and $\mathrm{T}_{7^{-}}$ Chlorpyrifos@ $10 \mathrm{ml} /$ litre of water recorded $18.33,14.00,11.33,8.00$ and 6.33 live grubs /tree, respectively.

According to Rajapakse et al., (1997) injection of quinalphos (2\%), into the galleries or tunnels made by the grub of pest significantly reduces pest menace. Whereas, Senguttuvan and Mahadevan (1997) reported trunk and soil application of monocrotophos at $0.05 \%$ at an early stage of infestation@ @ I00 $\mathrm{ml}$ per $30 \mathrm{~cm}$ trunk perimeter and phorate $10 \mathrm{G}$ @ $100 \mathrm{~g}$ per $50 \mathrm{~cm}$ perimeter to be superior treatments with 70 per cent mortality and 6575 per cent recovery of trees. It was also cost effective. Trees with moderate and severe infestation could not be saved.

Post extraction prophylaxis (PEP) trials conducted in cashew plantations of DCR, Puttur for the management of CSRB using chlorpyriphos $(0.2 \%)$, lindane $(0.2 \%)$, monocrotophos (0.2\%) and with entomopathogenic fungal spore suspensions of Metarhizium anisopliae, revealed tha, $\mathrm{t}$ chlorpyrifos $(0.2 \%)$ was the most effective pesticide in preventing loss of trees due to CSRB damage (Anon., 1998). 
Table.1 Effect of different treatments on CSRB grubs after ten days of application

\begin{tabular}{|c|c|c|}
\hline Treatment details & $\begin{array}{c}\text { No. of Dead } \\
\text { grubs per tree }\end{array}$ & $\begin{array}{c}\text { No. of live } \\
\text { grubs per tree }\end{array}$ \\
\hline T1-Dichlorvos@10 ml/tree / litre of water & $4.33(2.18)^{b}$ & $8.00(2.88)^{\text {cde }}$ \\
\hline T2-Dichlorvos@20 ml/tree & $5.66(2.32)^{b}$ & $1.00(1.22)^{\mathrm{gh}}$ \\
\hline $\mathrm{T}_{3}$-Dimethoate@10 ml/tree & $2.33(1.67)^{\mathrm{bc}}$ & $3.66(2.03)^{\mathrm{efg}}$ \\
\hline $\mathbf{T}_{4}$-Dimethoate @ $20 \mathrm{ml} /$ tree tree/litre of water & $2.66(1.71)^{b c}$ & $1.00(1.17)^{\mathrm{gh}}$ \\
\hline T5-Aluminium Phosphide @ 10 gm/tree & $18.66(4.36)^{\mathrm{a}}$ & $0.33(0.87)^{\mathrm{h}}$ \\
\hline T6- Chlorpyrifos@ 20 ml/tree & $0.33(0.70)^{\mathrm{cd}}$ & $4.66(2.25)^{\mathrm{ef}}$ \\
\hline T/-Chlorpyrifos@ $10 \mathrm{ml} /$ litre of water & $0.66(1.05)^{\mathrm{cd}}$ & $6.33(2.59)^{\mathrm{de}}$ \\
\hline $\mathbf{T}_{8}$-Carbosulfan@10 gm per tree & $1.33(1.34)^{\mathrm{cd}}$ & $1.66(1.46)^{\mathrm{fgh}}$ \\
\hline T9-Nepthalene Balls 4 /tree & $0.00(0.70)^{\mathrm{d}}$ & $11.33(3.41)^{\mathrm{bcd}}$ \\
\hline $\mathbf{T}_{10}$-Camphour 5 pieces / tree & $0.00(0.70)^{\mathrm{d}}$ & $14.00(3.64)^{\mathrm{abc}}$ \\
\hline$T_{11}-$ Only polythene sheet wrapping & $0.00(0.70)^{\mathrm{d}}$ & $18.33(4.31)^{\mathrm{ab}}$ \\
\hline $\mathbf{T}_{12}$-Untreated control & $0.00(0.70)^{d}$ & $20.00(4.50)^{\mathrm{a}}$ \\
\hline SEm \pm & 0.22 & 0.33 \\
\hline CD@ $9 \%$ & 0.67 & 0.97 \\
\hline
\end{tabular}

According to the findings of Mahadevan and Senguttuvan (1999) swabbing the basal trunk of cashew trees with $\mathrm{BHC}[\mathrm{HCH}] 0.2 \%$, coal tar + kerosene (1:2), neem [Azadirachta indica] oil $25 \%$, NSKE [neem seed kernel extract] $25 \%$, neem cake extract $25 \%$, karanj [Pongamia pinnata] oil 25\%, mahua [Madhuca longifolia] oil 25\%, white cement and waste oil, spraying fenthion $0.1 \%$ and pasting with red earth were compared for $P$. ferrugineus control in field trials in Tamil Nadu, India. Results indicated that spraying with fenthion, or swabbing with $\mathrm{HCH}$, coal tar +kerosene or neem oil to a height of $1 \mathrm{~m}$ from the ground 4 times a year, during March, June, September and December, was found effective in reducing $P$. ferrugineus incidence by $70-90$ per cent. Fenthion was the cheapest of the effective treatments, and neem oil was the most expensive. Management of CSRB on cashew was reported to be through post extraction prophylaxis after mechanical removal of the larvae of pest and later by application of chlorpyrifos $(0.2 \%)$ to each pest infested tree at the zone of pest incidence (Anon., 2004). But all the earlier studies indicates that, CSRB management practices were made by swabbing and injecting the chemicals to the cashew trunk. Present study enlightened on the insecticide application along with the transparent polythene stripe wrapping to the main trunk gave the best results in death of the CSRB grubs.

In conclusion, the present study revealed that, among the different treatments, significantly 
the highest number of CSRB dead grubs was recorded in $\mathrm{T}_{5}$-Aluminium Phosphide @ 10 $\mathrm{gm} /$ tree followed by $\mathrm{T}_{1}$ - Dichlorvos @ 10 $\mathrm{ml} /$ tree / litre of water and $\mathrm{T}_{2}$-Dichlorvos@ $20 \mathrm{ml} /$ tree. Application of these treatments along with polythene stripe wrapping to the main trunk may be used for effective management of CSRB without scrapping the cashew tree trunk for killing the grubs.

\section{References}

Anonymous, 1998. NRCC Annual Report. National research Centre for Cashew, ISSN \# 0972-2637 pp. 50-51.

Anonymous, 2004. All India Coordinated Cashew Improvement Project, Annual Report 2003-04, (Eds. T.N. Raviprasad and M. Gopalkrishna Bhat), National Research Centre for Cashew, Puttur, Karnataka, India. pp. 62-13.

Mahadevan, N. R. and Senguttuvan, T., 1999. Prophylactic control of stem and root borer (Plocaederus ferrugineus) in cashew (Anacardium occidentale).
Indian J. Agric. Sci., 69(2):163- 165. Rajapakse, R., Jopper, C. P., Caligari, P. D. S., Kullaya, A. K., Shomari, S.H., Kasuga, L. J., Masaaawe, P. A. L. and Mpunami, A. A., 1997. Proceeding of the international cashew and coconut conference. Dares Salaam, Tanzania., 17- 2 1, February: 165-169.

Senguttuvan, T. and Mahadevan, N. R., 1997. Studies on the population fluctuation and management of cashew stem and root borer, Plocaederus ferrugineus L. Pest Management in- Horticultural Ecosystems., 3(2): 85-94.

National Pulses Research Centre (TNAU), Vamban Colony - 622 303, Tamil Nadu, India.

Sundararaju, D. 1993. Studies on the parasitoids of tea mosquito bug, Helopeltis antonii Sign. (Heteroptera: Miridae) on cashew with special reference to Telenomus sp. (Hymenoptera: Scelionodae). J. Biol. Control., 7(1): 6-8.

\section{How to cite this article:}

Lakshmana, Mahesh Math and Ranganath, T. R. 2020. Evaluations of Insecticides against Cashew Stem and Root Borer, Neoplocaederus ferrugineus (L.). Int.J.Curr.Microbiol.App.Sci. 9(03): 2149-2152. doi: https://doi.org/10.20546/ijcmas.2020.903.245 